\title{
AKIBAT HUKUM JAMINAN FIDUSIA YANG TIDAK DIDAFTARKAN MENURUT UU NOMOR 42 TAHUN 1999
}

\author{
Muhammad Hilmi Akhsin*, Anis Mashdurohatun ${ }^{* *}$ \\ * Mahasiswa Program Magister (S2) Kenotariatan Fakultas Hukum UNISSULA \\ ** Dosen Fakultas Hukum UNISSULA
}

\section{ABSTRACT}

Fiduciary agreements by notarial deed are not sufficient, but should be continued with fiduciary registrants. Fiduciary agreements set forth in notarial deeds without registration do not grant preferential rights to fiduciary recipients. Whereas the objective of Law Number 42 Year 1999 is basically to provide legal protection for creditors from losses caused by default from debtor. From this, the authors in this thesis take the title "Consequences of Fiduciary Guaranty Laws Not Registered According to Law Number 42 Year 1999." With the scope of the issues covered include: (1) How the procedure or implementation of credit with fiduciary guarantee in Indonesia; (2) What are the constraints and solutions in the implementation of credit with fiduciary guarantee in Indonesia, and (3) What are the consequences of fiduciary guarantee law enlisted under Law No. 42 of 1999.

To obtain the results of research from these problems, the authors use the scientific method with an approach that is juridical empirical and normatiif. Empirically that is researching secondary data first and then continued by conducting research of primary data in field. The jurisdiction is to study the rules that exist with the problem in the perusal.

Furthermore, from the results of the research can obtain the understanding that the first, that the credit agreement made by debtors and creditors is the principal agreement that refers to the general principles of the agreement, while the imposition of fiduciary collateral meruapakan follow-up agreement or accesoir, which registers it has been regulated by Law No. 42 of 1999 , And set further through Government Regulation No. 21 of 2015; Second, the registration of fiduciary security is a creditor's obligation, but sometimes the creditor does not register it, for cost reasons or because the treaty deed is made under the hand. Therefore, the right of the fiduciary guarantee certificate is categorized as a treaty under the hand. Therefore, the solution taken by the creditors can make the settlement by deliberation or applying through the judiciary. Third, Fiduciary Guarantees must be made by the Deed of Natariil (Notarial Deed) and registered to the Office of the Ministry of Justice and Human Rights, in order to have executorial power, in addition, the creditor will obtain the preferred right. If fiduciary warranties are not made under the hands and are not registered in accordance with legislative provisions, they have no executorial force, and the right of preference and may become void (vernitigbarheid).

Whereas to further realize the main principle of Fiduciary Guarantee provides legal protection for the parties, it is necessary to revise the regulation of fiduciary guarantee in legislation in order to give more legal certainty.

Keywords: Fiduciary Security, Registration Procedures, and Legal Effects

\section{PENDAHULUAN}

Jaminan adalah menjamin dipenuhinya kewajiban yang dapat dinilai dengan uang yang timbul dari suatu perikatan hukum. Hukum jaminan berkaitan erat dalam hubungannya dengan hukum benda-benda. ${ }^{1} \quad$ Menurut ketentuan Pasal 2 Ayat (1) Surat Keputusan Direksi Bank Indonesia Nomor 23/69/KEP/DIR tanggal 28 Pebruari 1991 tentang Jaminan Pemberian Kredit menyatakan bahwa:

\footnotetext{
${ }^{1}$ Mariam Darus Badrulzaman, Bab-Bab Tentang Credietverband, Gadai dan Fiducia, Bandung, Citra Aditya Bakti, 1991), hlm. 21
} 
"Jaminan adalah suatu keyakinan bank atas kesanggupan debitor untuk melunasi kredit sesuai dengan yang diperjanjikan".

Menurut Undang-Undang Nomor 4 tahun 1996 tentang Hak Tanggungan,atas hak-hak yang dst (untuk selanjutnya disebut dengan UU Hak Tanggungan), pengertian jaminan fidusia diperluas dalam arti benda bergerak yang berwujud maupun tidak berwujud dan benda tidak bergerak yang tidak dapat dibebani dengan hak tanggungan. ${ }^{2}$ Jaminan fidusia adalah hak jaminan atas benda bergerak yang tetap berada dalam penguasaan pemberi fidusia, sebagai agunan pelunasan utang tertentu yang memberikan kedudukan yang diutamakan kepada penerima fidusia terhadap kreditor lainnya.

Undang-undang No. 42 Tahun 1999 tentang Jaminan Fidusia merupakan salah satu peraturan yang memberikan kepastian hukum di dalam masyarakat mengguna jaminan fidusia. Hal tersebut dapat dilihat pada Pasal 1 butir 2 Undang-undang No. 42 Tahun 1999 tentang Jaminan Fidusia yang menyatakan bahwa "sebagai agunan bagi pelunasan utang tertentu, yang memberikan kedudukan yang diutamakan kepada penerima fidusia terhadap kreditor lainnya". Berdasarkan hal tersebut maka status perjanjian kredit dengan jaminan fidusia memang efektif untuk memberikan perlidungan baik untuk kepentingan debitor maupun kreditor. Untuk kepentingan kreditor, hal tersebut dilandasi dalam Pasal 27 ayat (3) Undang-Undang Jaminan Fidusia, yang menyatakan bahwa suatu perjanjian dengan jaminan fidusia selain memberikan kedudukan yang diutamakan kepada penerima fidusia terhadap para kreditor lainnya, juga hak tersebut tidak akan hapus dengan adanya kepailitan dan atau likuidasi pemberi fidusia.

Di dalam perjanjian jaminan fidusia, baik penerima fidusia maupun pemberi fidusia menurut undang-undang jaminan fidusia samasama diberikan perlindungan hukum, bagi

2 Ignatius Ridwan Widyadharma, Hukum Jaminan Fidusia Pedoman Praktis, Cetakan ke-1, (Semarang:Universitas Diponegoro, 1999), hlm. 7 pemberi perlindungan berupa adanya hak pakai atas benda jaminan, dan wanprestasi pemberi jaminan tidak akan menyebabkan benda jaminan berubah hak kepemilikannya. UndangUndang Jaminan Fidusia memberikan hak preferen atas piutangnya dan berlakunya asas droit de suite atas benda jaminan, bagi pihak ketiga asas publisitas dalam perjanjian jaminan fidusia akan memberikan informasi terhadap benda-benda yang difidusiakan.

Menurut Pasal 11 Undang-Undang Jaminan Fidusia mengatakan bahwa:

1. Benda yang dibebani dengan Jaminan Fidusia wajib didaftarkan.

2. Dalam hal benda yang dibebani dengan Jaminan Fidusia berada diluar Wilayah Negara Republik Indonesia, kewajiban sebagaimana dimaksud dalam ayat (1) tetap berlaku.

Fidusia memiliki manfaat bagi debitor dan kreditor. Manfaat bagi debitor, yaitu dapat membantu usaha debitor dan tidak memberatkan, debitor juga masih dapat menguasai barang jaminannya untuk keperluan usahanya karena yang diserahkan adalah hak miliknya, sedangkan benda masih dalam penguasaan penerima kredit (debitor), sementara itu, keuntungannya bagi kreditor, dengan menggunakan prosedur pengikatan fidusia lebih praktis karena pemberi kredit tidak perlu menyediakan tempat khusus untuk penyimpanan barang jaminan fidusia seperti pada lembaga gadai. Keuntungan atau kelebihan lain yang diperoleh kreditor menurut ketentuan Pasal 27 Undang-Undang Nomor 42 Tahun 1999 Tentang Jaminan Fidusia (yang selanjutnya disebut dengan Undang-Undang Jaminan Fidusia) yaitu bahwa kreditor atau penerima fidusia memiliki kelebihan yaitu mempunyai hak yang didahulukan (preferent), adanya kedudukan sebagai kreditur preferent dimaksudkan agar penerima fidusia mempunyai hak didahulukan untuk mengambil pelunasan piutangnya atas hasil eksekusi benda yang menjadi objek jaminan fidusia yang tidak hapus karena adanya kepailitan dan atau likuidasi debitor atau pemberi fidusia. Berdasarkan ketentuan di atas, berarti terdapat 
perlindungan hak bagi penerima fidusia dan atau kreditor berdasarkan objek jaminan fidusia dari suatu perjanjian kredit yang diadakan antara kreditor dengan debitor, terhadap kemungkinan terjadinya wanprestasi oleh debitor.

Perlindungan hak yang diberikan oleh ketentuan Pasal 27 Undang-Undang Jaminan Fidusia tersebut dapat dilakukan jika benda yang menjadi objek jaminan fidusia tersebut didaftarkan, hal ini sesuai dengan ketentuan Pasal 11 ayat (1) Undang-Undang Jaminan Fidusia yang mengatur bahwa benda yang dibebani dengan jaminan fidusia wajib didaftarkan, artinya, terhadap benda yang telah dibebani jaminan fidusia seperti yang termuat dalam Akta Jaminan Fidusia berdasarkan perjanjian pokoknya yaitu perjanjian kredit, maka untuk selanjutnya, wajib didaftarkan di Kantor Pendaftaran Fidusia pada Kantor Wilayah Departemen Hukum dan Hak Asasi Manusia Republik Indonesia di tempat kedudukan pemberi fidusia.

Berdasarlam pasal dalam Undang-undang Jaminan Fidusia sendiri tidak ada satupun ketentuan yang mengatakan bahwa fidusia yang tidak didaftarkan adalah tidak sah, sehingga ketentuan tersebut di atas dapat ditafsirkan bahwa: Untuk berlakunya ketentuan-ketentuan dalam Undang-undang Fidusia maka haruslah dipenuhi syarat, bahwa benda jaminan fidusia Itu Didaftarkan. Fidusia yang tidak didaftarkan tidak bisa menikmati keuntungan-keuntungan dari ketentuanketentuan yang ada di dalam Undang-undang Jaminan Fidusia (Pasal 37 sub 3 Undangundang Jaminan Fidusia).

Perjanjian fidusia secara akta notariil saja tidak cukup, akan tetapi harus dilanjutkan dengan pendaftar fidusia. Perjanjian fidusia yang dituangkan dalam akta notariil tanpa pendaftaran tidak memberikan hak preferent bagi penerima fidusia. Namum demikian, tidak ada pengaturan yang tegas dalam UndangUndang Jaminan Fidusia mengenai siapa yang harus mengeksekusi benda jaminan fidusia, padahal benda jaminan fidusia merupakan benda bergerak yang sangat riskan perpindahannya, akibatnya penerima fidusia dalam penerapan di lapangan sulit melaksanakan asas droit de suite.

Pada akhirnya, banyak bank dalam melakukan perjanjian pembiayaan mencantumkan kata-kata dijaminkan secara fidusia, tetapi tidak dibuat dalam akta notarill dan tidak didaftarkan di Kantor Pendaftaran Fidusia untuk mendapat sertifikat. Padahal kemajuan teknologi dan peralihan sistem yang dibuat oleh Kementrian Hukum dan Hak Asasi Manusia (Kemenkumham) telah memudahkan pendaftaran jaminan fidusia pada Kantor Fidusia, yaitu pendaftaran secara on line yang hanya bisa dilakukan oleh notaris.

Dengan demikian maka meskipun akta jaminan fidusia dibuat secara notariil dihadapan notaris, akan tetapi tidak dilanjutkan dengan pendaftaran jaminan fidusia maka dapat dikatakan bahwa akta tersebut adalah akta jaminan fidusia dibawah tangan. Bank sebagai kreditur menjadi tidak memiliki hak didahulukan (lihat Pasal 27 ayat (1) UUJF) terhadap kreditur lain dalam pengembalian pinjamannya karena penjaminan secara fidusia dianggap tidak sah jika tidak didaftarkan.

Ketidaktegasan pasal-pasal dalam Undangundang Jaminan Fidusia dalam kewaijban pendaftaran fidusia mengakibatkan pihak perbankan tidak melakukan kewajiban pendaftaran fidusia segera setelah dilakukan penandatanganan akta jaminan fidusia yang mengikuti perjanjian kredit. Tidak jarang pihak bank baru melakukan pendaftaran jaminan fidusia pada saat terjadi indikasi debitur akan melakukan wanprestasi, misalnya pembayaran angsuran atau cicilan tidak tepat waktu. Padahal saat pencairan kredit, biasanya biaya pendaftaran fidusia dibebankan kepada debitur dan dipotong langsung dari jumlah nilai kredit yang diterima.

Hal ini yang mendasari penulis untuk melakukan penelitian dengan judul "Akibat Hukum Jaminan Fidusia Yang Tidak Didaftarkan Menurut UU Nomor 42 Tahun 1999." 
Tujuan yang hendak dicapai dengan dilakukannya penelitian ini adalah: Untuk mengetahui dan menganalisis bagaimana prosedur atau pelaksanaan kredit dengan jaminan fidusia di PT Summit OTTO Cabang Kendal, Untuk mengetahui dan menganalisis apa hambatan dan solusi dalam pelaksanaan kredit dengan jaminan fidusia di PT Summit OTTO Cabang Kendal, Untuk mengetahui dan menganalisis apa akibat hukum jaminan fidusia yang tidak di daftarkan menurut UU No 42 Tahun 1999.

\section{METODE PENELITIAN}

Metode pendekatan yang dipergunakan dalam penelitian ini menggunakan pendekatan yang bersifat yuridis empiris, yaitu suatu pendekatan yang meneliti data sekunder terlebih dahulu dan kemudian dilanjutkan dengan mengadakan penelitian data primer di lapangan. Secara yuridis yaitu mempelajari aturan-aturan yang ada dengan masalah yang di teliti. Sedangkan secara empiris yaitu memberikan kerangka pembuktian ata kerangka pengujian untuk membuktikan atau kerangka pengujian untuk meastikan suatu kebenaran.

Faktor yuridis dalam penelitian ini adalah UU Nomor 42 Tahun 1999 tentang Jaminan Fidusia, UU Nomor 10 Tahun 1998 tentang Perubahan atas UU Nomor 7 Tahun 1992 tentang Perbankan, Peraturan Pemerintah Republik Indonesia Nomor 86 Tahun 2000 tentang tata cara pendaftaran jaminan fidusia, biaya pembuatan sertipikat jaminan fidusia, peraturan lain yang berkaitan jaminan fidusia.

Spesifikasi penelitian ini adalah deskriptif analitis yang dimaksudkan untuk memberi data seteliti mungkin tentang suatu keadaan atau gejala-gejala lainnya. Penelitian ini diharapkan mampu memberi gambaran secara rinci, sistematis dan menyeluruh, mengenai segala hal yang berhubungan dengan perlindungan hukum debitur dari kelalain kreditur dalam Jaminan Fidusia yang telah dibuat Akta Notaris dan problematika hukumnya.
Jenis data dalam penelitian ini terdiri dari: Data primer adalah data yang diperoleh dari sumber-sumber asli. Data primer dalam penelitian ini adalah hasil wawancara yang diperoleh dari para informan yang menjadi sumber data dalam penelitan ini. Para informan tersebut adalah:Kepala Kanwil Kementrian Hukum dan Hak Asasi Manusia Divisi Jawa Tengah, Notaris. Sedangkan Data sekunder adalah data yang merupakan hasil olahan dari data mentah. Dokumen dalam penelitian ini berupa akta Perjanjian Kredit, akta Jaminan Fidusia dan Sertipikat Jaminan Fidusia yang sudah diterbitkan. Data sekunder juga termasuk data yang diperoleh dari studi kepustakaan yang berasal dari literatur dan peraturan perundang-undangan yang terdiri dari: Bahan hukum primer yaitu bagian dari data sekunder yang mempunyai kekuatan mengikat dan harus ada dalam penelitian ini yaitu: UU No. 10 Tahun 1998 tentang Perubahan UU No. 7 Tahun 1992 tentang Perbankan, UU No 42 Tahun 1999 tentang Fidusia, Kitab Undang-Undang Hukum Perdata, Akta perjanjian kredit dan akta jaminan fidusia yang dibuat oleh notaris

Data primer diperoleh dari Kepala Kanwil Kemenkumham, dan Notaris, Data sekunder, diperoleh dari hasil penelusuran pustaka, dokumentasi perpustakaan, internet dan sumber-sumber lain yang dijadikan sumber informasi utama.

Teknik analisis data dalam penelitian ini adalah deskriptif kualitatif. Deskriptif menjelaskan atau menggambarkan kenyataankenyataan yang terjadi pada obyek penelitian secara tepat dan jelas untuk memperoleh kejelasan tentang masalah yang timbul, sedangkan kualitatif adalah menganalisis datadata yang ada berdasarkan teori-teori yang berkaitan dengan masalah yang diteliti, kemudian apa yang dikemukakan oleh responden, baik lisan maupun tertulis, diteliti dan dipelajari mengenai permasalahan penelitian. 


\section{HASIL PENELITIAN DAN PEMBAHASAN}

\section{Prosedur atau Pelaksanaan Kredit dengan Jaminan Fidusia di PT. Summit OTTO Finance Cabang Kendal.}

\section{Prinsip-prinsip umum pemberian kredit}

Jaminan kredit yang diberikan oleh nasabah kepada bank atau lembaga pembiayaan hanyalah merupakan tambahan, yang bertujuan untuk melindungi kredit yang macet akibat wanprestasi dari debitor. Sebelum kredit diberikan oleh bank atau lembaga pembiayaan, terlebih dahulu harus dilakukan penelitian secara mendalam sehingga nasabah sudah dinyatakan layak untuk menerima kredit. Oleh karena itu, dalam pemberian kredit kepada debitor, bank harus memperhatikan prinsip-prinsip kehati-hatian, artinya bank atau lembaga pembiayaan sebelum memberikan kredit kepada debitor harus merasa yakin terlebih dahulu bahwa kredit yang diberikan benar-benar akan kembali. Keyakinan tersebut tentunya diperoleh dari hasil penelitian atau penilaian dari bebera unsur terhadap debitror.

Menurut Setyawati, ${ }^{3}$ ada beberapa prinsipprinsip penilaian kredit yang sering dilakukan yaitu dengan analisis 5C (Cbaracter, Capacity/Capabality, Capital, Colleteral, dan Condition), yaitu:

a. Cbaracter adalah sifat atau watak seseorang dalam hal ini calon debitor. Tujuannya adalah memberikan keyakinan pada bank bahwa sifat atau watak dari orang-orang yang akan diberikan kredit benar-benar dapat dipercaya. Keyakinan ini tercermin dari latar belakang si nasabah/calon debitor, baik yang bersifat latar belakang pekerjaan maupun yang bersifat pribadi seperti: cara

3 Hasil wawancara dengan Setyawati, Kemenkumham, Kota Semarang, pada tanggal 5 Juli 2017, di Semarang. hidup atau gaya hidup yang dianutnya, keadaan keluarga, hobi, dan cocial standingnya. Cbaracter merupakan ukuran untuk menilai "kemauan" nasabah atau calon debitor membayar kreditnya.

b. Capacity atau capabality bahwa untuk melihat kemampuan calon nasabah dalam membayar kreditnya dihubungkan dengan kemampuannya mengelola bisnis serta kemampuannya mencari laba. Sehingga pada akhirnya akan terlihat kemampuannya dalam mengembalikan kredit yang disalurkan. Semakin banyak sumber pendapat seseorang semakin besar kemampuannya untuk membayar kredit.

c. Capital biasanya bank tidak akan memenuhi permintaan kredit $100 \%$ artinya setiap nasabah atau calon debitor yang mengajukan permohonan kredit harus pula menyediakan dana dari sumber lainnya atau modal sendiri dengan kata lain capital adalah untuk mengetahui sumber-sumber pembiayaan yang dimiliki nasabah terhadap usaha yang akan dibiayai oleh bank.

d. Colleteral adalah merupakan jaminan yang diberikan calon nasabah bank yang bersifat fisik maupun nonfisik. Jaminan hendaknya melebihi jumlah kredit yang diberikan. Jaminan juga harus diteliti keabsahannya sehingga jika terjadi suatu masalah, jaminan yang dititipkan akan dapat dipergunakan secepat mungkin. Fungsi jaminan adalah sebagai pelindung bank dari kerugian.

e. Condition bahwa penilaian juga dilakukan terhadap keadaan ekonomi nasabah atau calon debitor sekarang serta predisksi yang akan datang. Kondisi ekonomi yang kurang stabil sangat mempengaruhi kemampuan nasabah untuk mengembalikan kreditnya. Oleh karena itu, hal ini sangat berpengaruh akan diperolehnya kredit bagi debitor.

Menurut penulis langkah-langkah di atas merupakan keharusan bagi oleh pihak bank atau lembaga pembiayaan keuangan untuk menjamin adanya kerugian yang dideritanya. Lagi pula, tidak sedikit para debitor yang pada saat mengajukan 
permohonan pinjaman atau perjanjian kredit dalam posisi yang dinilai memiliki kemampuan untuk melaksanakan prestasinya, namun karena perjalanan waktu yang tidak dapat diprediksi bisa juga berbalik keadaan yang semula lancar berubah menjadi macet.

Perlakukan bank atau lembaga pembiayaan keuangan tersebut, sejalan dengan prinsip perbankan yakni adanya prinsip kehatihatian (Prudential Banking Principles).

\section{Prosedur pemberian kredit}

Setelah pihak bank atau lembaga pebiayaan keuangan melakukan penelitian atau penilaian terhadap nasabah atau calon debitor, langkah selanjutnya sebelum debitor memperoleh kredit terlebih melalui tahapantahapan sebagai berikut:

a. Pengajuan Proposal kredit dan dokumendokumen yang diperlukan yang bersisi antara lain:

1) Riwayat perusahaan (jika yang mengajukan perusahaan), misalnya jenis bidang usaha, nama pengurus berikut latar belakang pendidikannya, perkembangan perusahaan, neraca perusahaan, serta wilayah pemasaran produknya.

2) Tujuan pengambilan kredit, dalam hal ini harus jelas tujuan penggunaannya.

3) Besarnya kredit dan jangka waktu.

4) Cara pengembalian kredit;

5) Jaminan kredit.

Secara umum ketentuan persyaratan permohonan kredit telah ditentukan oleh bank baik permohonan yang diajukan oleh perudahaan atau perseorangan. Oleh karenanya, bagi pemohon kredit berkewajiban untuk memenuhi persyaratan yang telah ditentukan dimaksud.

b. Penyelidikan berkas pinjaman, kegiatan ini dimaksudkan untuk membuktikan kebenaran dan keaslian dari berkas-berkas yang diajukan.

c. Penilaian kelayakan kredit, merupakan langkah yang sangat penting dilakukan karena untuk mengetahui berbagai aspek terhadap calon debitor berkaian dengan mengembalian kreditnya. Kegiatan ini dapat dilakukan dengan menggunakan prinsipprinsip $5 \mathrm{C}$ yang diuaraikan terdahulu.

d. Wawancara pertama, tahap ini merupakan penyidikan kepada calon debitor dengan cara berhadapan langsung dengan pihak bank. Tujuannya adalah untuk mendapatkan keyakinan apakah berkas-berkas sesuai dan lengkap seperti yang diinginkan. Di samping itu, juga untuk mengetahui keinginan dan kebutuhan nasabah sebenarnya.

e. Peninjauan ke lokasi (on the spot), setelah memperoleh keyakinan dan kebenaran terhadap dokumen-dokumen dimaksud, maka langkah selanjutnya adalah melakukan peninjauan ke lokasi yang menjadi objek kredit. Tujuan peninjauan kelapangan tidak lain adalah untuk memastikan bahwa objek yang dijadikan jaminan atau yang dibiayai benar-benar ada dan sesuai dengan apa yang ditulis dalam proposal.

f. Wawancara kedua, merupakan kegiatan perbaikan berkas jika ditemukan adanya perbedaan antara dokumen yang ada dengan hasil peninjaun lapangan.

g. Keputusan Kredit, setelah melalui berbagai peniilaian mulai dari kelengkapan dokumen, keabsahan dan keasilan dokumen serta penilaian yang meliputi selurh aspek studi kelayakan kredit, maka langkah selanjutnya adalah keputusan kredit.

h. Penandatangan akad kredit/perjanjian lainnya.

Kegiatan ini merupakan kelanjutan dari dikabulkannya permohonan kredit. Sebelum kredit dicaikan terlebih dahulu pemohon kredit harus menandatangani akad kredit, kemudian mengikat jaminan kredit dengan hipotik atau surat jaminan yang dianggap perlu misalnya jaminan fidusia.

i. Realisasi kredit, setelah akad kredit ditandatangani, maka langkah selanjutnya adalah merealisasikan kredit. Realisasi kredit diberikan setelah calon nasabah menandatangani surat-surat yang 
diperlukan dengan membuka rekening giro atau tabungan di bank yang bersangkutan. Dengan demikian penarikan kredit dapat dilakukan melalui rekening bank yang telah dibuka.

Mencermati prosedur perolehan kredit dimaksud, dapat di peroleh pemahaman bahwa jaminan fidusia lahir setelah adanya perjanjian pokok yakni kredit yang telah disetuji dan ditandatanganinya domuken permohonan kredit oleh debitor. Klausul jaminan fidusia harus termuat dalam penjanjian induknya karena menurut Pasal 1 butir 2 UU Nomor 42 Tahun 1999, menegaskan bahwa jaminan fidusia sebagai agunan bagi pelunasan utang tertentu, yang memberikan kedudukan yang diutamakan kepada penerima fidusia terhadap kreditur lainnya. Perjanjian fudisia merupakan perjanjian assesoir dari suatu perjanjian pokok yang menimbulkan kewajiban bagi para pihak untuk memenuhi suatu prestasi yang berupa memberikan sesuatu, berbuat sesuatu atau tidak berbuat sesuatu yang dapat dinilai dengan uang.

Menurut teori perbankan, yakni prinsip kehati-hatian (Prudential Banking Principles) dalam rangka penyaluran kredit kepada perusahaan-perusahaan dan masyarakat untuk kepentingan pembiayaan, maka setiap bank diwajibkan untuk melaksanakan prinsip kehatihatian dalam menyalurkan kredit-kreditnya. Hal ini didasarkan karena resiko yang sangat tinggi dalam melakukan pemberian kredit sebagai usaha utama bank. Selain itu, kegagalan di bidang kredit dapat berakibat pada terpengaruhnya kesehatan dan kepercayaan bank itu sendiri.

Pengaturan prinsip kehati-hatian (Prudential Banking Principles) dapat dilihat dalam Undang-Undang Nomor 23 Tahun 1999 tentang Bank Indonesia Pasal 25 menegaskan bahwa:

"Ayat (1) Dalam rangka melaksanakan tugas mengatur bank, Bank Indonesia berwenang menetapkan ketentuanketentuan perbankan yang memuat prinsip kehati-hatian;"

\begin{abstract}
"Ayat (2) Pelaksanaan kewenangan sebagaimana dimaksud pada ayat (1) ditetapkan dengan Peraturan Bank Indonesia."
\end{abstract}

Mencermati kedua pasal tersebut bahwa prinsip kehati-hatian bank bertujuan untuk memberikan rambu-rambu bagi penyelenggaraan kegiatan usaha perbankan guna mewujudkan sistem perbankan yang sehat. Mengingat pentingnya tujuan mewujudkan sistem perbankan yang sehat, maka peraturan-peraturan dibidang perbankan harus didukung dengan sanksisanksi yang adil.

Terkait dengan sistem jaminan fidusia yang merupakan objek penelitian, menurut penulis merupakan salah satu cara pihak bank untuk menjamin pengembalian kredit yang telah diberikan kepada debitor. Hal ini tidak lain untuk menjamin tetap eksisnya bank dalam menjalankan usahanya.

\section{Tata Cara Perdaftaran Jaminan Fidusia}

Setelah diundangkannya Undang-Undang Nomor 42 Tahun 1999 tentang Jaminan Fidusia selanjutnya disebut Undang-Undang Nomor 42 Tahun 1999, Pemerintah mengeluaran peraturan tata cara pendaftaran jaminan fidusia sebagaimana yang diamanatkan oleh ketentuan Pasal 5 ayat (2) dan Pasal 13 ayat (4) UU Nomor 42 Tahun 1999, ${ }^{4}$ yakni Peraturan Pemerintah Nomor 86 Tahun 2000 tentang Tata Cara Pendaftaran Jaminan Fidusia dan Biaya Pembuatan Akta Jaminan Fidusia (Lembaran Negara Republik Indonesia Nomor 170 Tahun 2000, Tambahan Lembaran Negara Republik Indonesia Nomor 4005), selanjutnya disebut PP Nomor 86 Tahun 2000. ${ }^{5}$ Namun dalam perjalanan waktu PP Nomor 86 Tahun 2000, dianggap sudah tidak sesuai lagi dengan perkembangan hukum dan kebutuhan masyarakat, sehingga perlu adanya aturan atau regulasi baru yang dapat memenuhi kebutuhan masyarakat dimaksud. Selanjutnya, sejak April

\footnotetext{
4 UU Nomor 42 Tahun 1999.

5 PP Nomor 86 Tahun 2000.
} 
tahun 2015 lalu, Pemerintah menerbitkan Peraturan Pemerintah (PP) Nomor 21 Tahun 2015 tentang Tata Cara Pendaftaran Jaminan Fidusia dan Biaya Pembuatan Akta Jaminan Fidusia, selanjutnya disebut PP Nomor 21 Tahun 2015. Perbedaan yang mendasar aturan antara PP 86 Tahun 2000 dengan PP Nomor 21 Tahun 2015, mengenai pengaturan tata cara pendaftaran Jaminan Fidusia secara elektronik. Pada prinsipnya, substansi yang diatur dalam Peraturan Pemerintah ini tidak berbeda jauh dengan pengaturan yang terdapat dalam Peraturan Pemerintah Nomor 86 Tahun 2000 tentang Tata Cara Pendaftaran Jaminan Fidusia dan Biaya Pembuatan Akta Jaminan Fidusia. ${ }^{6}$

Peraturan Pemerintah ini merupakan aturan pelaksana ketentuan Pasal 5 ayat (2) dan Pasal 13 ayat (4) UU Nomor 42 Tahun 1999 tentang Jaminan Fidusia, yang selengkapnya berbunyi:

Pasal 5 ayat (1) dan ayat (2):

Ayat (1) : Pembebanan Benda dengan Jaminan Fidusia dibuat dengan akta notaris dalam bahasa Indonesia dan merupakan akta Jaminan Fidusia.

Ayat (2) : Terhadap Pembuatan akta Jaminan Fidusia sebagai mana dimaksud dalam ayat (1), dikenakan biaya yang besarnya diatur lebih lanjut dengan Peraturan Pemerintah.

Selanjutnya, berdasarkan Pasal 37 ayat (2) dan Pasal 39 Undang-Undang Nomor 42 Tahun 1999 tentang Jaminan Fidusia dibentuk Kantor Pendaftaran Fidusia yang berada dalam lingkup tugas Kementerian Hukum dan Hak Asasi Manusia dengan wilayah kerja mencakup seluruh wilayah Indonesia. Dalam memberikan pelayanan kepada masyarakat, berdasarkan PP Nomor 21 Tahun 2015, Kantor Pendaftaran Fidusia yang semula melakukan pendaftaran Jaminan Fidusia secara manual dan ternyata pada penerapannya memiliki beberapa kendala, antara lain tidak tercapainya pelayanan one day

\footnotetext{
6 PP Nomor 21 Tahun 2015
}

service karena permohonan yang masuk sangat banyak melampaui kemampuan sumber daya manusia dan sarana yang ada. Untuk mengatasi permasalahan tersebut, maka pemerintah merasakan perlu diciptakan pola pelayanan pendaftaran Jaminan Fidusia secara elektronik (online system).

Menurut Setyowati, ${ }^{7}$ dengan diterbitkannya PP Nomor 21 Tahun 2015, Kementerian Hukum dan Hak Asasi Manusia (Kemenkum dan HAM), sebagai Kantor Pelayanan Pendaftaran Jaminan Fidusia, merasa sangat diringkan beban kerjanya karena tata cara pendaftaran Jaminan Fidusia yang semula diatur secara manual sekarang pendaftaran diatur melalui online. Dalam hal penyelesaiannya pun juga sangat berbeda luar biasa, semula memakan waktu 30 hari, dengan cara online cukup membutuhkan 7 menit. Sejalan dengan pendapat Setyawati, Rinto menegaskan bahwa tata cara pendaftaran Jaminan Fidusia dengan adanya PP Nomor 21 Tahun 2015, lebih mudah dan cepat dibandingkan dengan aturan yang lama (PP Nomor 86 Tahun 2000).

Menurut penulis beberapa ketentuan baru yang termuat dalam Peraturan Pemerintah ini, antara lain:

1) Adanya kewajiban bagi Penerima Fidusia, kuasa atau wakilnya untuk memberitahukan penghapusan Jaminan Fidusia, sebagaimana diatur dalam Pasal 16 dan Pasal 17 UU Nomor 42 Tahun 1999.

Pemberitahuan penghapusan tersebut tidak dikenakan biaya. Dengan tidak adanya biaya yang dikenakan diharapkan Penerima Fidusia, kuasa atau wakilnya dapat melakukan pemberitahuan penghapusan Jaminan Fidusia tersebut dengan sukarela dan tanpa beban. Hal ini akan memudahkan bagi Kementerian

7 Hasil wawancara dengan Setyawati, Kemenkumham, Kota Semarang, pada tanggal 5 Juli 2017, di Semarang.

8 Hasil wawancara dengan Rinto, PT. Otto Summit Finance, Semarang, pada tanggal 6 Juli 2017 di Semarang. 
Hukum dan Hak Asasi Manusia untuk melakukan pemantauan terhadap Jaminan Fidusia yang sudah berakhir atau akan berakhir jangka waktunya.

2) Besarnya biaya pembuatan akta Jaminan Fidusia ditentukan berdasarkan nilai penjaminan yangmengacu pada besarnya biaya pembuatan akta yang diatur dalam Pasal 36 ayat (3) Undang-Undang Nomor 30 Tahun 2004 tentang Jabatan Notaris sebagaimana telah diubah denganUndangUndang Nomor 2 Tahun 2014 tentang Perubahan atas Undang-Undang Nomor 30 Tahun 2004 tentang Jabatan Notaris.

3) Adanya ketentuan bahwa seluruh data yang diisi dalam permohonan pendaftaran Jaminan Fidusia,permohonan perbaikan sertifikat Jaminan Fidusia, permohonan perubahan sertifikatJaminanFidusia, dan pemberitahuan penghapusan sertifikat Jaminan Fidusia secara elektronik sertapenyimpanan dokumen fisiknya menjadi tanggung jawab Penerima Fidusia, kuasa atau wakilnya. ${ }^{9}$

4) Saat ini tidak hanya Notaris saja yang dapat mengakses pendaftaran Jaminan Fidusia.

5) Pihak-pihak lain seperti multifinance maupun masyarakat dapat pula mengakses pendaftaran jaminan fidusia melalui www.ahu.go.id

1. Tempat Pendaftaran

Pasal 11 Undang-Undang Nomor 42 Tahun 1999 menegaskan bahwa benda yang dibebani dengan Jaminan Fidusia wajib didaftarkan; Dalam hal benda yang dibebani Jaminan Fidusia berada di luar wilayah negara Republik Indonesia, kewajiban sebagaimana dimaksud ayat (1) tetap berlaku.

Pendaftaran Jaminan Fidusia dilakukan pada Kantor Pendaftar Fidusia yang mencakup wilayah kerja Kementerian Hukum dan HAM di Provinsi.

Namun dengan lahirnya PP Nomor 21 Tahun 2015, sistem pendaftaran dilakukan melalui

\footnotetext{
9 Penjelasan Umum PP Nomor 21 Tahun 2015.
}

online. Sebagaimana ditegaskan dalam pertimbangan huruf (a), bahwa untuk meningkatkan pelayanan pendaftaran jaminan fidusia dengan mudah, cepat, dan biaya rendah, perlu dilakukan pelayanan pendaftaran jaminan fidusia secara elektronik. Hal ini ditegaskan kembali Pasal 2 ayat (2) PP Nomor 21 Tahun 2015, menegaskan bahwa Permohonan sebagaimana dimaksud pada ayat (1) diajukan melalui sistem pendaftaran Jaminan Fidusia secara elektronik.

\section{Perubahan Serifikat Jaminan Fidusia}

Pasal 11 PP Nomor 21 Tahun 2015, menegaskan bahwa apabila terjadi kesalahan pengisian data dalam permohonan pendaftaran Jaminan Fidusia mengenai jumlah nilai jaminan sebagaimana di maksud Pasal 3 huruf e dalam kategori nilai peminjaman yang berbeda. Penerima Fidusia, kuasa atau wakilnya harus mengajukan permohonan perbaikan sertifikat Jaminan Fidusia kepada Menteri. Permohonan perubahan sertifikat Jaminan Fidusia sebagaimana dimaksud pada ayat (1) paling sedikit memuat:

a. nomor dan tanggal sertifikat terakhir;

b. nama dan tempat kedudukan notaris;

c. data perubahan; dan

d. keterangan perubahan.

Pasal 12 PP Nomor 21 Tahun 2015, menegaskan bahwa ayat (1), Permohonan perubahan sertifikat Jaminan Fidusia yang telah memenuhi ketentuan sebagaimana dimaksud dalam Pasal 11 memperoleh bukti pendaftaran. Ayat (2) bukti pendaftaran sebagaimana dimaksud pada ayat (1) paling sedikit memuat:

a. nomor pendaftaran;

b. tanggal pengisian aplikasi;

c. nama pemohon;

d. nama kantor pendaftaran Fidusia;

e. jenis permohonan; dan

f. biaya permohonan perubahan sertifikat Jaminan Fidusia.

Pemohon melakukan pembayaran biaya permohonan perubahan sertifikat Jaminan Fidusia melalui bank persepsi berdasarkan bukti pendaftaran. Pendaftaran perubahan sertifikat 
Jaminan Fidusia dicatat setelah pemohon melakukan pembayaran. Sertifikat perubahan atas sertifikat Jaminan Fidusia sebagaimana dimaksud dalam Pasal 7 dapat dicetak setelah pembayaran biaya permohonan dilakukan. Sertifikat perubahan dapat dicetak pada tanggal yang sama dengan tanggal permohonan perubahan sertifikat Jaminan Fidusia dicatat. Sertifikat perubahan ditandatangani secara elektronik oleh Pejabat pada Kantor Pendaftaran Fidusia.

\section{Penghapusan Jaminan Fidusia}

Pasal 16 PP Nomor 21 Tahun 2015, menegaskan bahwa Jaminan Fidusia hapus karena: (a) hapus karena hapusnya utang yang dijamin dengan fidusia; (b) pelepasan hak atas Jaminan Fidusia oleh Penerima Fidusia; (c) musnahnya benda yang menjadi objek Jaminan Fidusia. Dalam hal Jaminan Fidusia hapus sebagaimana dimaksud dalam Pasal 16 di atas, maka Penerima Fidusia, kuasa atau wakilnya, wajib memberitahukan kepada Menteri dalam jangka waktu paling lama 14 (empat belas) hari terhitung sejak tanggal hapusnya Jaminan Fidusia.

Pemberitahuan penghapusan Jaminan Fidusia paling sedikit memuat: (a) ketentuan atau alasan hapusnya Jaminan Fidusia; (b) nomor dan tanggal sertifikat Jaminan Fidusia; (c) nama dan tempat kedudukan notaris; dan (b) tanggal hapusnya Jaminan Fidusia.

Berdasarkan pemberitahuan penghapusan tersebut, Jaminan Fidusia dihapus dari daftar Jaminan Fidusia dan diterbitkan keterangan penghapusan yang menyatakan sertifikat Jaminan Fidusia yang bersangkutan tidak berlaku lagi. Jika Penerima Fidusia, kuasa atau wakilnya tidak memberitahukan penghapusan Jaminan Fidusia maka Jaminan Fidusia yang bersangkutan tidak dapat didaftarkan kembali. $^{10}$

10 Peraturan Pemerintah Nomor 21 Tahun 2015 tentang Tata Cara Pendaftaran Jaminan Fidusia dan Biaya Pembuatan Akta Jaminan Fidusia, (Lembaran Negara Republik Indonesia Tahun 2015 Nomor 80,
Terhadap seluruh data yang diisi dalam permohonan pendaftaran jaminan fidusia, permohonan perbaikan sertifikat Jaminan Fidusia, permohonan perubahan sertipikat Jaminan Fidusia, dan pemberitahuan penghapusan sertipikat Jaminan Fidusia secara elektronik serta penyimpanan dokumen fisiknya menjadi tanggung jawab Penerima Fidusia, kuasa atau wakilnya. (Vide Pasal 19 PP Nomor 21 Tahun 2015). Sedangkan seluruh data yang tersimpan dalam pangkalan data sebagai hasil proses pendaftaran Jaminan Fidusia mempunyai kekuatan yang sama dengan buku daftar fidusia. (Vide Pasal 20 PP Nomor 21 Tahun 2015).

\section{Hambatan dan Solusi Dalam Pelaksanaan Kedit dengan Jaminan Fidusia di Indonesia.}

Menurut Setyawati, ${ }^{11}$ hambatanhambatan dan Upaya Penyelesaian Dalam Pelaksanaan Perjanjian Kredit dengan Jaminan Fidusia Berdasarkan hasil penelitian dapat diketahui bahwa hambatan utama dari pelaksanaan perjanjian kredit dengan Jaminan Fidusia muncul ketika terjadi wanprestasi dari pihak debitor, yang disebabkan oleh berbagai faktor:

1. Usaha debitor mengalami kegagalan;

2. Kredit yang disalurkan tidak dipergunakan sebagaimana mestinya (tidak sesuai dengan tujuan pengajuan kredit) oleh debitor;

3. Debitor tidak beritikad baik untuk memenuhi kewajibannya;

4. Keadaan perekonomian secara nasional yang juga membawa pengaruh terhadap kondisi keuangan debitor;

5. Hal-hal lain yang diluar prediksi.

Dalam kondisi tersebut upaya eksekusi merupakan upaya yang harus dilakukan untuk menyelamatkan kredit yang telah disalurkan agar tidak menjadi Non Performance Loans (NPL) bagi pihak bank. Upaya eksekusi

Tambahan Lembaran Negara Republik Indonesia Nomor 5691).

${ }^{11}$ Hasil wawancara dengan Ro'fah Setyawati, Op.Cit. 
merupakan upaya terakhir yang ditempuh setelah upaya restrukturisasi dan upaya pendekatan secara musyawarah mufakat gagal dilakukan.

Sejalan dengan pendapat Ro'fah Setyawati, Rinto, ${ }^{12}$ menambahkan bahwa dalam prakteknya terdapat beberapa kendala dalam melakukan eksekusi jaminan fidusia, yaitu:

1. Sita eksekusi tidak dapat diletakkan pada Objek jaminan fidusia Meskipun Pasal 23 ayat (2) Undang-Undang Nomor 42 Tahun 1999 tentang Jaminan Fidusia, menentukan bahwa pemberi fidusia dilarang mengalihkan, menggadaikan atau menyewakan objek jaminan fidusia kecuali dengan persetujuan tertulis lebih dahulu dari penerima-fidusia. Namun dalam prakteknya timbul suatu permasalahan, dalam hal pemegang jaminan fidusia mohon sita eksekusi terhadap objek fidusia ternyata objek jaminan fidusia tersebut telah dibeli oleh pihak ketiga secara beritikad baik, pihak ketiga tersebut berdasarkan Pasal 1977 KUHPerdata dapat percaya bahwa barang bergerak orang yang menguasai (membezit) barang tersebut adalah pemiliknya (bezit geldt als volkomen title).

2. Merupakan suatu kendala bagi bank selaku kreditor pemegang fidusia dalam hal akan menjual objek jaminan fidusia melalui mekanisme menjual atas kekuasaan sendiri dengan mohon bantuan Kantor Lelang/Balai Lelang untuk menjual objek jaminan fidusia sesuai dengan bunyi Pasal 15 ayat (3) Undang-Undang Jaminan Fidusia, akan tetapi barang yang menjadi objek jaminan fidusia tidak diketemukan atau dikuasai oleh orang lain, dalam hal ini tentunya Kantor Lelang/Balai Lelang tidak dapat melakukan penjualan lelang objek fidusia tersebut.

3. Objek Jaminan Fidusia Hilang. Apabila kita cermati lebih lanjut ketentuan Pasal 15 ayat Op.Cit.
12 Hasil wawancara dengan Rinto Ardiyanzah,
(2) Undang-Undang Jaminan Fidusia, yang mengatakan sebagai berikut :

"Sertifikat jaminan fidusia sebagaimana dimaksud dalam ayat (1) mempunyai kekuatan eksekutorial yang sama dengan putusan pengadilan yang telah memperoleh kekuatan hukum pasti.

4. Objek jaminan telah beralih/dijual kepada pihak ketiga lainnya

5. Objek jaminan sudah tidak ada/hilang.

6. Objek jaminan telah berubah bentuk

7. Objek jaminan tagihan yang hanya merupakan daftar/surat pernyataan pemberian fidusia yang tidak terinformasikan dasar-asar penerbitannya tidak dapat dilakukan eksekusinya.

Kekuatan eksekutorial sebagaimana dimaksudkan pada Pasal 15 ayat (2) UU No. 42 Tahun 1999 tersebut adalah langsung dapat dilaksanakan tanpa melalui Pengadilan Negeri dan bersifat final serta mengikat para pihak untuk melaksanakan putusan tersebut. Terhadap peiaksanaan eksekusi putusan pengadilan yang telah memperoleh kekuatan hukum tetap harus mengacu pada ketentuan Pasal 195 HIR dan selanjutnya, artinya bahwa eksekusi putusan pengadilan yang telah memperoleh kekuatan hukum tetap dan bersifat serta merta harus dilakukan di bawah pimpinan Ketua Pengadilan Negeri yang berwenang. Oleh karena Pasal 15 ayat (2) Undang-Undang No. 42. Tahun 1999 menyebutkan sertifikat jaminan fidusia yang berisikan irah-irah "Demi Keadilan Berdasarkan Ketuhanan Yang Maha Esa" mampunyai kekuatan hukum eksekutorial yang sama dengan putusan pengadiian yang telah memperoleh kekuatan hukum tetap, maka eksekusi sertifikat jaminan fidusia yang berjudul "Demi Keadilan Berdasarkan Ketuhanan Yang Maha Esa" juga harus di bawah pimpinan Ketua Pengadilan Negeri yang berwenang.

Sebagaimana diketahui, proses eksekusi suatu putusan yang telah memperoleh kekuatan hukum tetap atau yang bersifat serta merta termasuk proses eksekusi sertifikat 
jaminan fldusia/hak tanggungan yang berjudul "Demi Keadilan Berdasarkan Ketuhanan Yang Maha Esa" mempunyai 3 (tiga) tahapan, yaitu :

1. Tahap peneguran, pada tahap ini debitor yang cidera janji diperingatkan untuk memenuhi kewajiban membayar utang dalam jangka waktu 8 (delapan) hari setelah diberi peneguran;

2. Tahap sita eksekusi, dalam hal debitor dalam jangka 8 (delapan) hari tersebut di atas, tidak juga memenuhi kewajibannya membayar hutang kepada kreditor, maka kreditor pemohon eksekusi (penggugat pemenang perkara atau kreditor pemegang hak tanggungan/kreditor pemenang jaminan fidusia) mohon kepada Ketua Pengadilan yang berwenang untuk melakukan sita eksekusi.

Dalam hal pemohon eksekusi adalah pemegang sertifikat jaminan fidusia atau pemegang hak tanggungan yang dirnohonkan sita eksekusi adalah objek jaminan fidusia, objek hak tanggungan. Atas permohonan sita eksekusi tersebut Ketua Pengadilan yang berwenang akan menerbitkan sita eksekusi dan kemudian jurusita melakukan sita eksekusi.

3. Tahap pelelangan, dalam hal setelah dilakukan sita eksekusi terhadap hak tanggungan atau objek fidusia (barang jaminan) debitor tetap tidak membayar hutangnya, maka atas permohonan pemohon eksekusi (kreditor pemegang sertifikat hak tanggungan atau sertifikat fidusia) Pengadilan yang berwenang akan menerbitkan penetapan pelelangan/penjualan umum, baru kemudian Kantor Lelang Negara akan melakukan pelelangan objek jaminan hak tanggungan atau objek fldusia. Tentunya setelah semua persyaratan yang diperlukan dipenuhi dan hasil penjualan lelang tersebut setelah dipenuhi dan hasil penjualan lelang tersebut setelah dikurangi biaya lelang dan biaya lain-lain diserahkan kepada kreditor pemohon eksekusi. Dalam hal ada sisa hasil penjualan lelang, tersebut harus diserahkan kembali kepada debitor.
Namun dalam prakteknya hal tersebut ternyata belum dapat dijadikan suatu upaya hukum yang efisien dalam melakukan eksekusi jaminan fidusia, mengingat permohonan eksekusi melalui title eksekutorial tersebut memerlukan rentang waktu yang cukup panjang dan membutuhkan biaya yang cukup besar. Sehingga proses eksekusi yang sederhana, cepat, murah dan efesien masih diperlukan dewasa ini bagi dunia perbankan. ${ }^{13}$

\section{Akibat Hukum Jaminan Fidusia yang tidak di daftarkan Menurut Undang-Undang Nomor 42 Tahun 1999}

Dengan tidak didaftarkannya jaminan fidusia sesuai ketentuan UU Nomor 42 Tahun 1999, dan aturan pelasananya, maka akta perjanjian fidusia dimaksud masuk ketegori perjanjian di bawah tangan, dan menyelesaiannyapun membutuhkan campur tangan pihak peradilan. Oleh karena itu, proses eksekusi harus dilakukan dengan cara pengajukan kepada pengadilan setelah putusannya mempunyai kekuatan hukum tetap. Proses eksekusi terhadap benda yang menjadi objek jaminan fidusia ataupun benda yang menjadi objek diluar jaminan fidusia, para pihak harus memperhatikan hak debitor yang melekat pada objek benda yang menjadi jaminan pinjaman dimaksud, karena dalm hal demikian, perlu diperhatikan bahwa terhadap obyek pembiayaan jaminan fidusia dalam perjalannnya tidak full sesuai nilai barang, karena debitor sudah melakukan prestasinya yakni telah membayar beberapa kali angsuran yang menjadi kewajibannya. Oleh karena itu, benda yang menjadi objek jaminan fidusia ada sebagian hak yang dimiliki oleh debitor, sebagian lainnya milik kreditor. Apabila eksekusi tersebut dilakukan secara paksa yakni dengan melalui jasa debt collector atau tukang

13 Sri Hartini, Pelaksanaan Perjanjian Kredit dengan Jaminan Fidusia di Koantor Pusat PT. Bank Bukopin Tbk. Jakarta, Tesis, Program Studi Magister Kenotariatan Universitas Diponegoro Semarang, 2008. 
tagih, hal ini tentunya akan melanggar hukum. Pelanggaran hukum tersebut dapat dikategorikan sebagai perbuatan melawan hukum sebagaimana dia atur dalam Pasal 1365 Kitab Undang-Undang Hukum Perdata, sehingga debitor dapat mengajukan gugatan melalui pengadilan untuk meminta gati kerugian atas perbuatan kreditor tersebut.

Disamping itu, menurut penulis tindakan sewenang-wenang yang dilakukan oleh kreditor dengan melalui debt collector atau penagih hutang tersebut dapat dikategorikan juga melanggar hukum pidana. Dalam praktiknya, oleh karena itu, perbuatan tersebut dikategorikan perbuatan yang melanggar Pasal 368 KUHPidana yang berbunyi: ${ }^{14}$

"Barang siapa dengan maksud untuk menguntungkan diri sendiri atau orang lain secara melawan hukum, memaksa seseorang dengan kekerasan atau ancaman kekerasan untuk memberikan barang sesuatu, yang seluruhnya atau sebagian adalah kepunyaan orang itu atau orang lain, atau supaya membuat hutang maupun menghapuskan piutang, diancam karena pemerasan dengan pidana penjara paling lama sembilan tahun"

Situasi ini dapat terjadi jika kreditor dalam eksekusi melakukan pemaksaan mengambil barang secara sepihak, padahal diketahui dalam barang tersebut sebagian atau seluruhnya milik orang lain. Walaupun juga diketahui bahwa sebagain dari barang tersebut adalah milik kreditor yang mau mengeksekusi tetapi tidak didaftarkan di kantor jaminan fidusia, maka perbuatan dimaksud tetap masuk kategori perbuatan melawan hukum dan melanggar hukum sebagaimana dijelaskan di atas. Terhadap tindakan kreditor yang secara paksa mengambil benda yang menjadi obyek jaminan fidusia, akan tetapi jaminan fidusia tersebut tidak didaftarkan, maka debitor dapat langsung melaporkan ke Kantor Kepolisian Republik Indonesia terdekat.

\footnotetext{
${ }^{14}$ Pasal 368 KUHPidana.
}

Akibat hukum lainnya, dapat pula kreditor mengalihkan objek fidusia yang dilakukan dibawah tangan kepada pihak lain, dalam ini debitor juga tidak dapat dijerat dengan UU Nomor 42 Tahun 1999, karena akta perjanjian di bawah tangan tidak sah menurut UU dimaksud. Oleh karena itu, mensikapi hal ini kadang kala kreditor melaporkan debitor kepada kepolisian atas tuduhan penggelapan sesuai ketentuan Pasal 372 KUHPidana, yang berbunyi:

"Barang siapa dengan sengaja dan atau melawan hukum memiliki barang sesuatu yang seluruhnya atau sebagian adalah kepunyaan orang lain, tetapi yang ada dalam kekuasaannya bukan karena kejahatan diancam karena penggelapan, dengan pidana penjara paling lama empat tahun atau pidana denda paling banyak sembilan ratus rupiah."

Menurut Rinto Ardiyanzah, ${ }^{15}$ langkah kreditor yang demikian pada dasarnya dibenarkan oleh undang-undang, akan tetapi jikalau kreditor juga melakukan perbuatan sewenang-wenang untuk mengambil benda jaminan fidusia dan sebaliknya debitor juga bertindak mengalihkan benda jaminan fidusia, maka hal ini akan terjadi saling melaporkan. Hal demikian terjadi menandakan sebagian besar lembaga pembiayaan keuangan belum memahami dan mentaati ketentuan yang diatur dalam UU Nomor 42 Tahun 1999. Padahal jika dicermati dengan adanya jaminan fidusia yang didaftarkan secara benar akan memberikan perlindungan hukum bagi kreditor. Keengganan mendaftarkan jaminan fidusia dimaksud, kemungkinan disebabkan adanya pembebanan biaya pada pihak kreditor. Di samping itu, mencermati pendapat Anta Winata, ${ }^{16}$ mengatakan bahwa pada dasarnya maksud dari Peraturan Menteri Keuangan tentang Kewajiban mendaftarkan jaminan fidusia memiliki sisi

15 Hasil wawancara dengan Rinto Ardiyanzah, Op.Cit. tanggal 5 Juli 2017

16 Anta Winata, Direktur Utama, PT. Bentara Sinergies Multifinance (Bess Finance), Artikel dimuat dalam Harian Jogja, tanggal 30 Agustus 2012. 
positif. "Pendaftaran fidusia memberikan kepastian hukum sehingga multifinance memiliki hak preferen apabila terjadi sengketa", Meski demikian, lanjutnya pendaftaran jaminan fidusia tidak menyelesaikan kendala dalam menarikan kendaraan apabila terjadi kredit macet. Bukan berarti dengan mendaftarkan fidusia serta merta kami jadi mudah menarik kendaraan. Penarikan kendaraan akan sama susahnya, apalagi kalau konsumennya sudah tidak ada atau kabur.

Menurut penulis ketentuan Pasal 36 UU Nomor 42 Tahun 1999, bahwa tersangka melarikan diri, identitasnya tidak jelas, pelaku tidak diketahui keberadaannya dan tidak dapat dilakukan penahanan pada tersangka.

Mencermati perkembangan lembaga pembiayaan keuangan, Kepala Eksekutif Pengawas Industri Keuangan Nonbank Otoritas Jasa Keuangan (OJK), Firdaus Djaelani, ${ }^{17}$ menegaskan akan memberikan sanksi bagi perusahaan pembiayaan yang mangkir dalam pendaftaran jaminan fidusia, akan memberikan surat peringatan kepada perusahaan pembiayaan, dan bukan tidak mungkin hingga pembekuan kegiatan usaha. Pendaftaran jaminan fidusia memang kerap menjadi perdebatan di beberapa kalangan. Ada yang menganggap tidak wajib, ada juga yang mengatakan sebaliknya. Djaelani mengingatkan, berdasar Peraturan Menteri Keuangan Nomor 130/PMK 010/2012, yang tidak wajib adalah mencantumkan klausula fidusia di perjanjian, jika klausula dimasukkan, pendaftaran wajib dilakukan.

Berdasar data, dari perusahaan pembiayaan yang terdaftar dan berada di bawah pengawasan OJK saat ini, sebanyak 99 persennya tercatat ada pembebanan fidusia sehingga wajib didaftarkan.

\section{PENUTUP}

17 Firdaus Djaelani, Materi acara Sosialisasi Pendaftaran Jaminan Fidusia Online di Hotel JW Marriot, Senin, 22 April 2013.
Dari uraian yang disampaikan sebelumnya, maka penulis dapat simpulkan sebagai berikut :

\section{Simpulan}

1. Prosedur atau Pelaksanaan Kredit dengan Jaminan Fidusia di Indonesia

Bahwa perjanjian kredit yang dibuat oleh debitor dan kreditor merupakan perjanjian pokok yang mengacu prinsip-prinsip umum perjanjian, sedangkan pembebanan jaminan fidusia meruapakan perjanjian ikutan atau accesoir, yang mendaftarannya telah diatur dengan UU Nomor 42 Tahun 1999, dan di atur lebih lanjut melalui Peraturan Pemerintah Nomor 21 Tahun 2015.

2. Hambatan dan Solusi Dalam Pelaksanaan Kedit dengan Jaminan Fidusia di Indonesia. Jaminan Fidusia merupakan perjanjian ikutan atau aksesoris, yang prinsip dasarkan memberikan perlindungan hukum kepada kreditor dari kerugian yang diakibatkan debitor cidera janji atau wanpresasi. Namun dalam praktiknya masih ditemukan persoalan-persoalan yang terjadi, baik berasal dari kreditor sendiri atau dari debitor. Dalam hal ini, kreditor yang menerima hak jaminan fidusia kadang kala tidak mendaftarkannya, dengan alasan biaya atau karena akta perjanjian dibuat di bawah tangan. Sedangkan dari pihak debitor, sering terjadi mengalihan hak benda jaminan fidusia kepada pihak ketiga, bahkan lebih dari itu lagi debitor melarikan diri dan tidak ditemukan alamatnya. Oleh karena itu, solusi yang diambil oleh kreditor dapat melaporkan debitor kepada Kantor Kepolisian Republik Indonesia dengan tuduhan penggelapan.

3. Akibat hukum Jaminan Fidusia yang tidak di daftarkan Menurut UU Nomor 42 Tahun 1999

Bahwa Jaminan fidusia harus dibuat dengan Akta Natariil (Akta Notaris) dan didaftarkan pada Kantor Kementerian Hukum dan HAM, agar memiliki kekuatan eksekutorial, di samping itu, kreditor akan memperoleh hak preferen. Apabila jaminan fidusia tidak dibuatkan dibawah tangan dan tidak 
didaftarkan sesuai kekentuan perundangundangan, maka tidak memiliki kekuatan eksekutorial, dan hak hak preferen serta dapat menjadi batal demi hukum (vernitigbarheid).

\section{Saran}

Bahwa prinsip utama Jaminan Fidusia diperuntukkan kepada kreditor agar terhindungi dari kerugian yang diakibatkan oleh terjadinya wanprestasi dari debitor, maka seharusnya kreditor tidak boleh lalai untuk membuat akta jaminan fidusia dengan Akta Natariil, dan juga didaftarkan melalui kantor pendaftaran Jaminan Fidusia.

Namun, masih ditemukannya akta jaminan fidusia yang tidak dibuat dengan Akta Notariil dan juga tidak didaftakannya jaminan fidusia dimaksud, karena Undang-undang tidak mengatur secara tegas. Oleh karena itu, kedepan perlu adanya revisi pengaturan jaminan fidusia dalam perundang-undangan dengan klausul mewajibkan dibuatnya Jaminan Fidusia dan Pendaftaran, apabila dilalaikan pihak yang bersangkutan mendapatkan sanksi. Dengan demikian, maka akan terjadinya suatu kepastian huk

\section{DAFTAR PUSTAKA}

A. Buku

A.A. Andi Prajitno, 2009, Hukum Fidusia, (Malang: Bayumedia Publishing).

Badriyah Harun, 2010, Penyelesaian Sengketa Kredit Bermasalah : Solusi Hukum (Legal Action) dan Alternatif Penyelesaian Segala Jenis Kredit Bermasalah, (Yogyakarta: Penerbit Pustaka Yustisia).

Ignatius Ridwan Widyadharma, 1999, Hukum Jaminan Fidusia Pedoman Praktis, Cetakan ke-1, (Semarang: Penerbit Universitas Diponegoro).

J. Satrio, 1993, Hukum Perikatan (Perikatan yang Lahir dari Undang-Undang), (Jakarta: Citra Aditya Bakti).

Kasmir, 2010, Dasar-dasar Perbankan, (Jakarta: PT. RajaGrafindo Persada).

M. Yahya Harahap, 1996, Segi-segi Hukum Perjanjian, (Bandung : Alumni).

Muhammad Djumhana, 2006, Hukum Perbankan di Indonesia, (Bandung: Citra Aditya Bhakti).

Purwahid Patrik, 1994, Dasar-Dasar Hukum Perikatan, (Bandung: Mandar Maju).

Purwahid Patrik dan Kashadi, 2008, Hukum Jaminan, Edisi Revisi dengan UUHT, (Semarang: FH Undip).

Salim HS, 2004, Perkembangan Hukum Jaminan di Indonesia, (Jakarta: Penerbit PT. Raja Grafindo Persada).

Sentosa Sembiring, 2000, Hukum Perbankan (Bandung: Mandar Maju).

Soeryono Soekamto dan Sri Mamuji, 2007, Penelitian Hukum Normatif-Suatu Tinjuan Singkat, (Jakarta: Rajawali Press).

Munir Fuady,2003,Jaminan Fidusia (Jakarta:PT Citra Aditya Bakti)

Racmadi Usman,2008,Hukum Jaminan Keperdataan (Jakarta:Sinar Grafika)

B. Peraturan Perundang-undangan

Kitab Undang-Undang Hukum Perdata

UU No 42 Tahun 1999 tentang Jaminan Fidusia

UU No 4 Tahun 1996 tentang Hak Tanggungan

UU No 2 Tahun 2008 tentang Perbankan

UU No 8 Tahun 1999 tentang Perlindungan Konsumen

Peraturan Pemerintah Republik Indonesia No 12 Tahun 2015 tentang Tata Cara 
pendaftaran Jaminan Fidusia dan Biaya Pembuatan Akta Jaminan Fidusia

Peraturan Menteri Keuangan Nomor 130/PMK.010/2012 tentang Pendaftaran Jaminan Fidusia Bagi Perusahaan Pembiayaan Yang Melakukan Pembiayaan Konsumen Untuk Kendaraan Bermotor Dengan Pembebanan Jaminan Fidusia

C. Jurnal atau artikel ilmiah, Karya ilmiah

Sibarani,Bachtiar,2001,Parate Eksekusi dan Paksa Badan,Jurnal Hukum Bisnis,Volume 15 Halaman 15

Intan Selasie Indranita,2009,Eksekusi Terhadap Jaminan Fidusia Yang Tidak Didaftarkan, Tesis Mkn Universitas Diponegoro
Indah Antari Mukti,2010,Perjanjian Kredit Dengan Jaminan Fidusia Atas Kendaraan Bermotor Yang Dijual Pada Pihak Ketiga Pada PT Bank Danamon (Persero)TBK Unit DSP Pracimantoro Wonogiri,Tesis Mkn Universitas Diponegoro

D. Internet

Nugroho,Grace P,2007,Tindakan Eksekutorial Terhadap Benda Obyek Jaminan Fidusia Dengan Akta DiBawahTangan ,www.suarakonsumen.com 